\title{
PSYCHE
}

\begin{tabular}{lll}
\hline Vol. 81 & June, I974 & No. 2 \\
\hline
\end{tabular}

\section{SOCIAL CARRYING BEHAVIOR AND DIVISION OF LABOR DURING NEST MOVING IN ANTS}

\author{
By Michael Möglich* and Bert Hölldobler \\ Biological Department, MCZ-Laboratories, \\ Harvard University, Cambridge, Mass., 02 I 38
}

Social carrying behavior is one of the most remarkable social activities in ant societies. Not only eggs, larvae and pupae, but also adult workers, queens and males are frequently carried by worker ants to various target areas. Although carrying behavior has been observed in many ant species (see review in E. O. Wilson 197I), only a few analytical investigations have dealt with the biological significance of social carrying behavior in ants. Kneitz (1964) reports that in Formica polyctena special "storage workers" are passively moved between the summer nest and winter nest. Arnoldi (I932) observed that during the slave raids Rossomyrmex proformicarum uses the carrying technique to recruit sister workers to the nest of the slave ants. In Camponotus herculeanus social carrying behavior serves as a "social timer" during the nuptial flight activities: males that tend to take off too early or too late during the daily flight periods are carried back into the nest by their worker nestmates (Hölldobler and Maschwitz 1964).

Most frequently, however, carrying behavior is employed during emigration from one nest site to another. If a nest becomes too small and cannot be extended, or if the microclimatic conditions change, the colony searches for a better site. Although the communication signals used by different ant species to organize nest movings vary considerably, adult transport seems to be the basic recruitment technique of most.

*Present address: Fachbereich Biologie, Frankfurt, W. Germany.

Manuscript received by the editor June 28, 1974. 


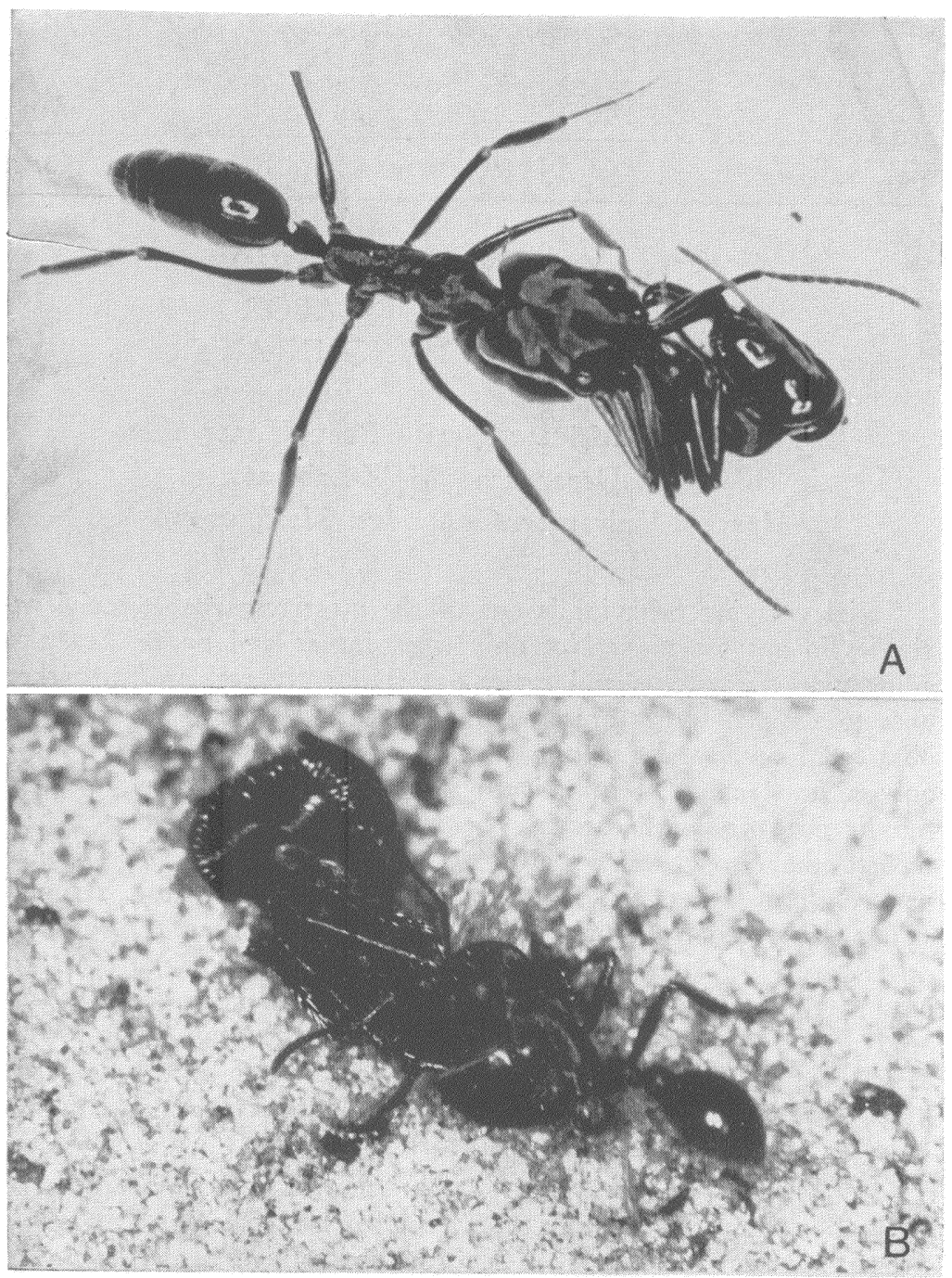

Fig. 1. Primitive adult transport in A) Odontomachus (worker carries worker) B) Pogonomyrmex badius (worker carries "soldier" caste). 


\section{The Specificity and Stereotypy of Carrying Behavior}

Escherich (1917) and Arnoldi (1932) pointed out that the behavioral patterns of adult transport in ants are very stereotyped and are often specific for certain taxonomical groups. These assumptions are confirmed by the following brief survey of adult transport behavior in ants.

\section{Myrmeciinae:}

In one of the most primitive genera of the myrmecoid complex, the Australian Myrmecia Haskins and Haskins 1950 observed adult transport. However, the behavioral patterns are apparently not stereotyped. One worker grasps another at the mandibles or any other part of the body and drags it over the ground.

\section{Dorylinae:}

According to Rettenmeyer ( 1963) workers of the New World army ants (tribe Ecitonini) carry other adults like larvae and pupae slung beneath the body and between the legs of the transporting worker.

\section{Ponerinae:}

An unstereotyped carrying behavior, similar to that described for Myrmecia, was observed by the present authors in Bothroponera tesserinoda. It occurs only rarely; nestmates are primarily recruited by the tandem running technique (see Maschwitz, Hölldobler and Möglich, in press). Somewhat more advanced is the adult transport behavior of Odontomachus. The transporter ant simply grasps a nestmate on a leg, the petiole or some other part of the body, lifts it up and carries it away. Although there is no general, stereotyped response, the transported individual usually folds its appendages tightly to the body (Fig. IA). Much more elaborate and stereotyped behavior is displayed by Rhyditoponera metallica. When the transporting worker approaches a nestmate head on, it repeatedly grasps the ant at the head and jerks it slightly forward. The movement lasts only $\mathrm{I}-2$ seconds. The nestmate responds by turning its bodyaxis slightly sideways, whereupon the transporting ant seizes the nestmate with a firm grip. After turning through an angle of approximately $180^{\circ}$, the transportee is lifted and curled over the head of the carrying ant. During transportation the gaster is bent inwards and the appendages folded tightly to the body.

\section{Myrmicinae:}

Although Escherich reports that in myrmicine ants the transported ant is grasped at the petiole and carried with the head and legs 


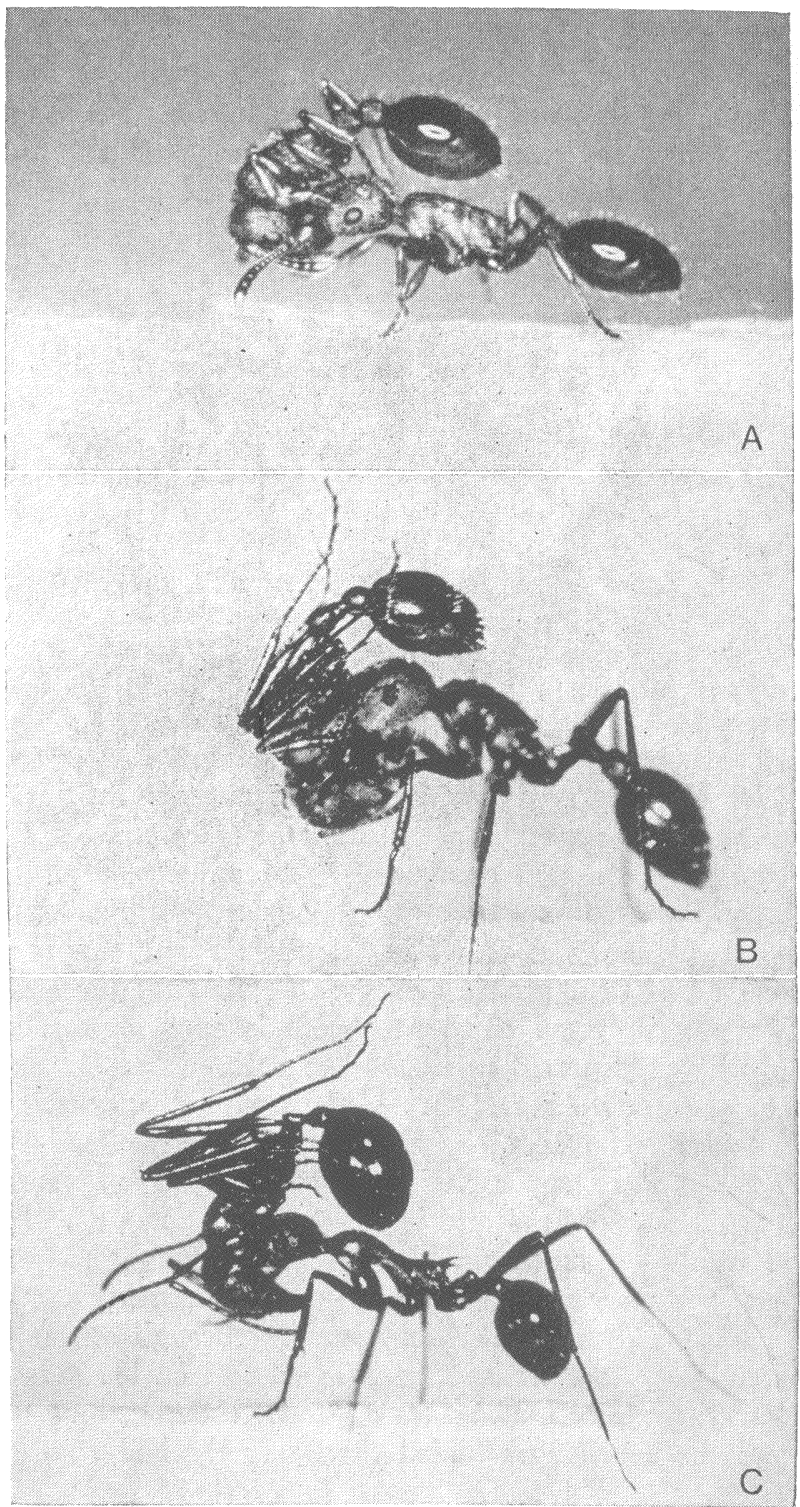

Fig. 2. Adult transport technique in myrmicine ants: A) Leptothorax nylanderi (worker carries worker). B) Pogonomyrmex maricopa (worker carries worker). C) Novomessor cockerelli (worker carries worker). 
pointed forward, in fact this seems to be the exception and has been specifically observed only in Crematogaster (see Wilson I97I). Generally, however, the stereotyped adult transport behavior of many myrmicine species, which has been repeatedly described since Escherich's time, resembles that of Rhyditoponera. The transportee is either seized at the mandibles or at the "neck" or "cheeks" and curled over the head of the transporting worker (Fig. 2). But there are a few other exceptions: we found, for example, that the harvesting ants Pogonomyrmex badius, $P$. rugosus and $P$. barbatus employ a rather primitive carrying technique. As in Odontomachus the transportee is grasped at any part of the body, lifted up and carried away. During transportation the carried individual folds its appendages to the body (Fig. Iв). This primitive transporting behavior is especially remarkable, because in some other Pogonomyrmex species, for example $P$. maricopa, we found the typical highly stereotyped adult transport behavior described above for other myrmicine ants (Fig. 2).

\section{Formicinae:}

The most uniform and stereotyped social carrying behavior can be observed in the subfamily Formicinae. In several species we have analyzed the behavioral patterns that initiate and guide carrying behavior and found them to be virtually invariant. For the following, more detailed description of this behavior we have chosen Camponotus sericeus, a common species on Ceylon. The description is based on single frame analyses of slow motion pictures (Fig. 3).

When a recruiting ant faces a nestmate head on, it conducts a jerking behavior for 2-3 seconds, grasping the nestmate at the mandibles and subsequently pulling it forward. Usually the recruiting ant responds by turning around for $180^{\circ}$. The nestmate is thereby slightly lifted, and this elevation evidently causes it to fold its legs tightly to the body and to roll the gaster inward. In this "pupal" posture it is then carried to the target area.

Identical stereotyped adult transport behavior has been observed in many formicine ants and has been described in particular detail in Formica rufa (Zahn 1957), F. polyctena (Kneitz 1964, Möglich 1971), Cataglyphis (Wehner and Lutz 1969), Camponotus socius (Hölldobler 197 I) and several other species.

\section{Sex specific carrying postures}

Reproductive females are sometimes carried like workers (Fig. 4). But in cases where the size difference is too large, workers merely 


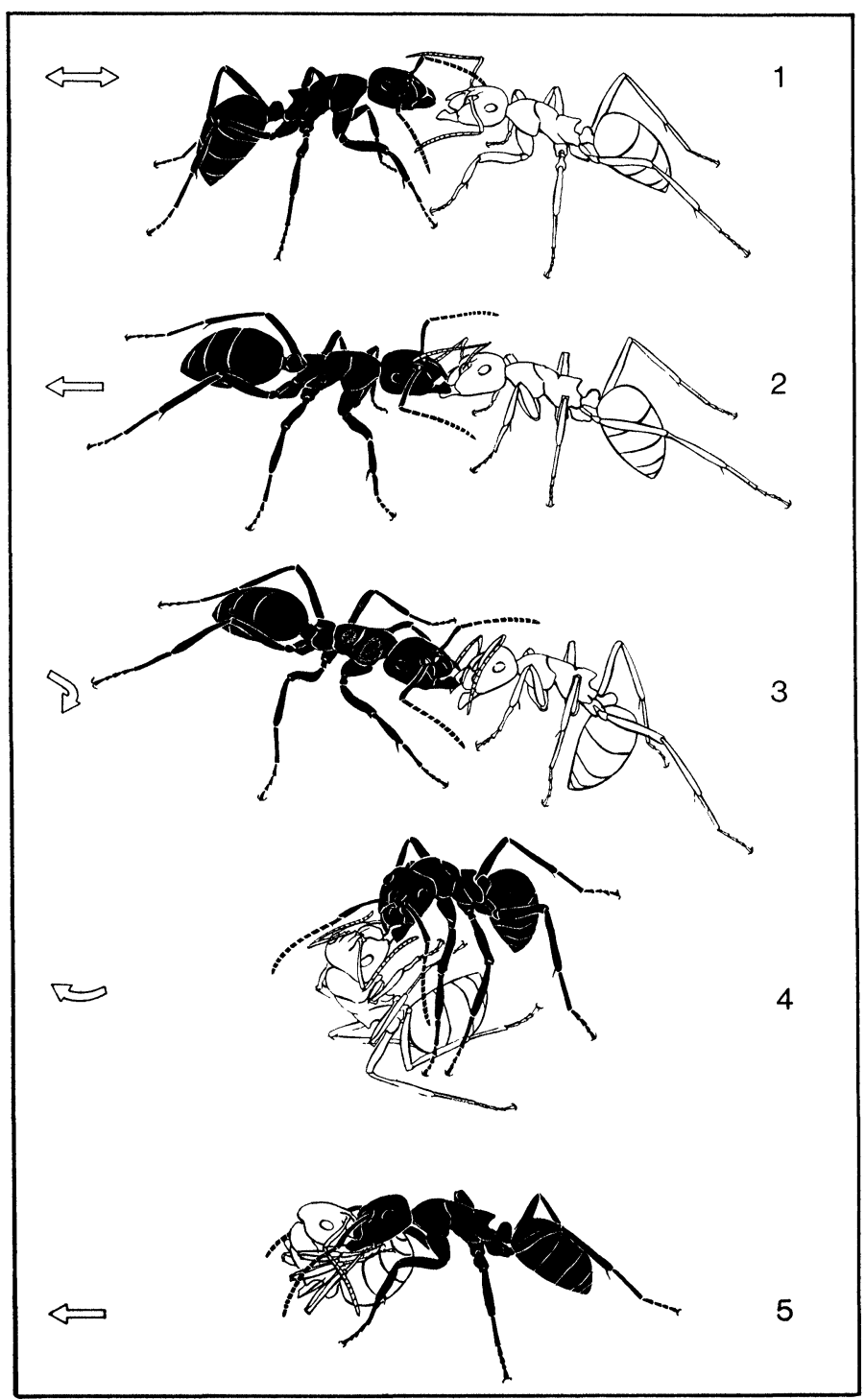

Figure 3 
grasp the females at the mandibles and pull them to the target area (Fig. 5). The first behavioral steps that lead to this pulling behavior are usually similar to those which initiate carrying behavior in workers.

The methods by which males are transported are notably different, however. These individuals are sometimes picked up at any part of the body and dragged or carried to the target area. In a few species workers apply specific stereotyped carrying methods for males. In several Camponotus species we observed that most of the males are grasped at the "neck" and lifted into an oblique position in which they are carried away (Fig. 6A). During transportation the males remain motionless with the antennae and legs folded to the body. As Fig. $6 \mathrm{~B}$ and $\mathrm{c}$ shows, there are occasionally exceptions of this carrying technique.

In some other species, as in Novomessor cockerelli and Aphaenogaster floridanus, workers grasp the males between the thorax and gaster and carry them beneath their body between their legs (Fig. 7).

\section{Division of Labor During Nest Movings}

Social carrying behavior in ants can serve many purposes; it is, however, most frequently employed during nest emigrations. Together with the tandem running technique it can be considered to be a rather primitive recruitment method. In both cases, each recruiting ant can only recruit one nestmate at one time. This leads to the question: Do all workers of a colony have the same carrier or tandem-leader potential, or is there instead a group of specialists, who organize nest movings. To investigate this matter we chose two formicine species, one which moves almost exclusively by using the adult transport method (Formica sanguinea) and another which primarily employs the tandem running technique (Camponotus sericeus).

Nest emigrations can be induced in the laboratory by keeping the

Fig. 3. The behavioral sequences that initiate carrying behavior. 1. The recruiter ant (black) approaches a nestmate (white) and conducts the jerking response for $2-3$ seconds. 2. The recruiter grasps the nestmate at the mandibles and pulls it back for about $2-20 \mathrm{~cm}$. 3 . When the recruiter turns, it holds the nestmate with a firm grip. The nestmate is thereby slightly lifted. 4. The nestmate folds its legs and antennae tightly to the body and rolls its gaster inward. 5. In this posture it is carried to the target area. The arrows indicate the direction of the movements. These sequences were based on a film analysis. (After Hölldobler, Möglich, Maschwitz 1974; illustrations by Turid Hölldobler). 

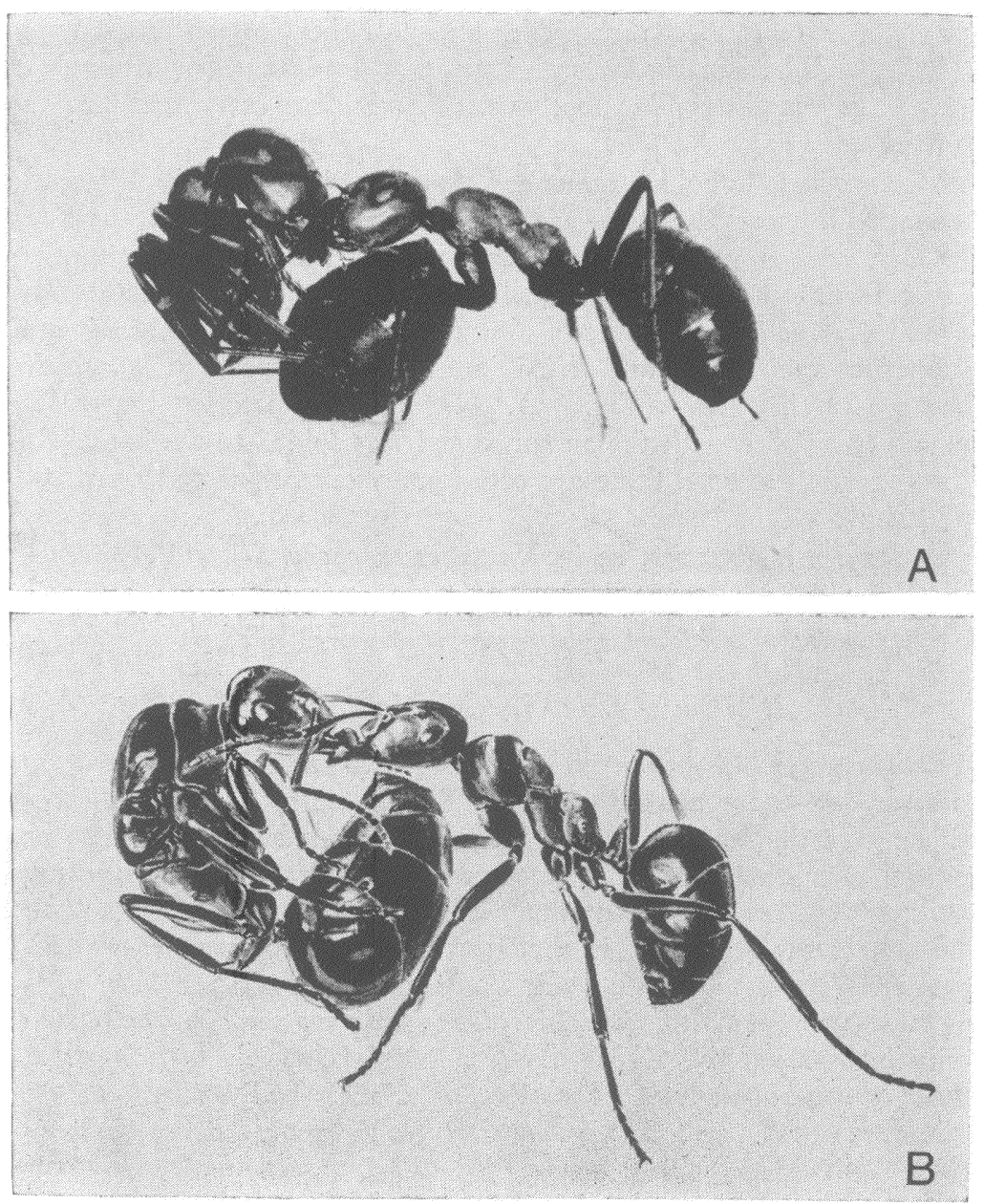

Fig. 4. Adult transport technique in formicine ants: A) Formica rufa worker carries a sister worker. B) Formica rufa worker carries a queen. 


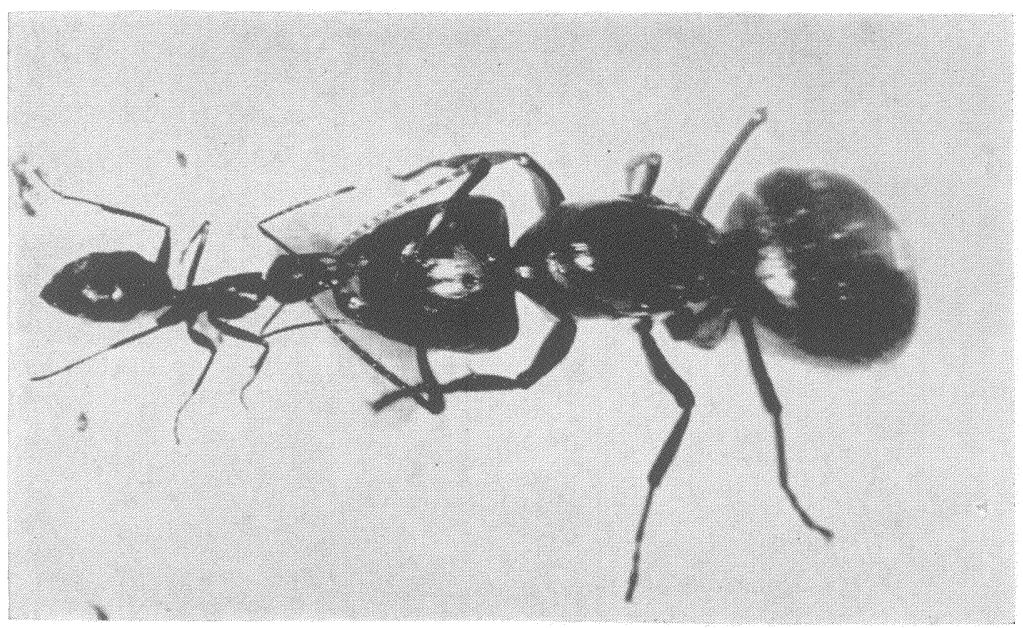

Fig. 5. If the difference of size between workers and queens becomes too large, queens are either pulled or led along a short odor trail to the target area. This is the case in young colonies of Camponotus pennsylvanicus.

old nest under less than optimal conditions while at the same time providing a new nest nearby with optimal conditions. Soon a scout discovers the new nest, and after a short inspection returns to the old nest. Usually it runs 2-3 times back and forth between the old and new nest, before beginning to recruit nestmates to the new site. Our intention was to identify and follow all individual workers of an entire colony throughout the experimental procedures. In order to do this we marked the ants individually by applying spots of one or the other of four colors at one or more of four pre-selected positions on the body. In this way we were able to recognize up to 256 workers individually. With each of our test colonies we conducted 20 nest-moving experiments over a period of about 2 months, before the entire colony was killed and each worker subsequently dissected.

During the nest emigrations we recorded the following parameters in particular: I) How often a worker was carried or led by tandem running, respectively, during all nest movings; 2) How often a worker functioned as a carrier or leader, respectively, during one nest-moving episode and throughout the entire experimental period of 20 movings. 3) We also distinguished between the recruitment intensity and the continuity of the recruitment activity of workers. 


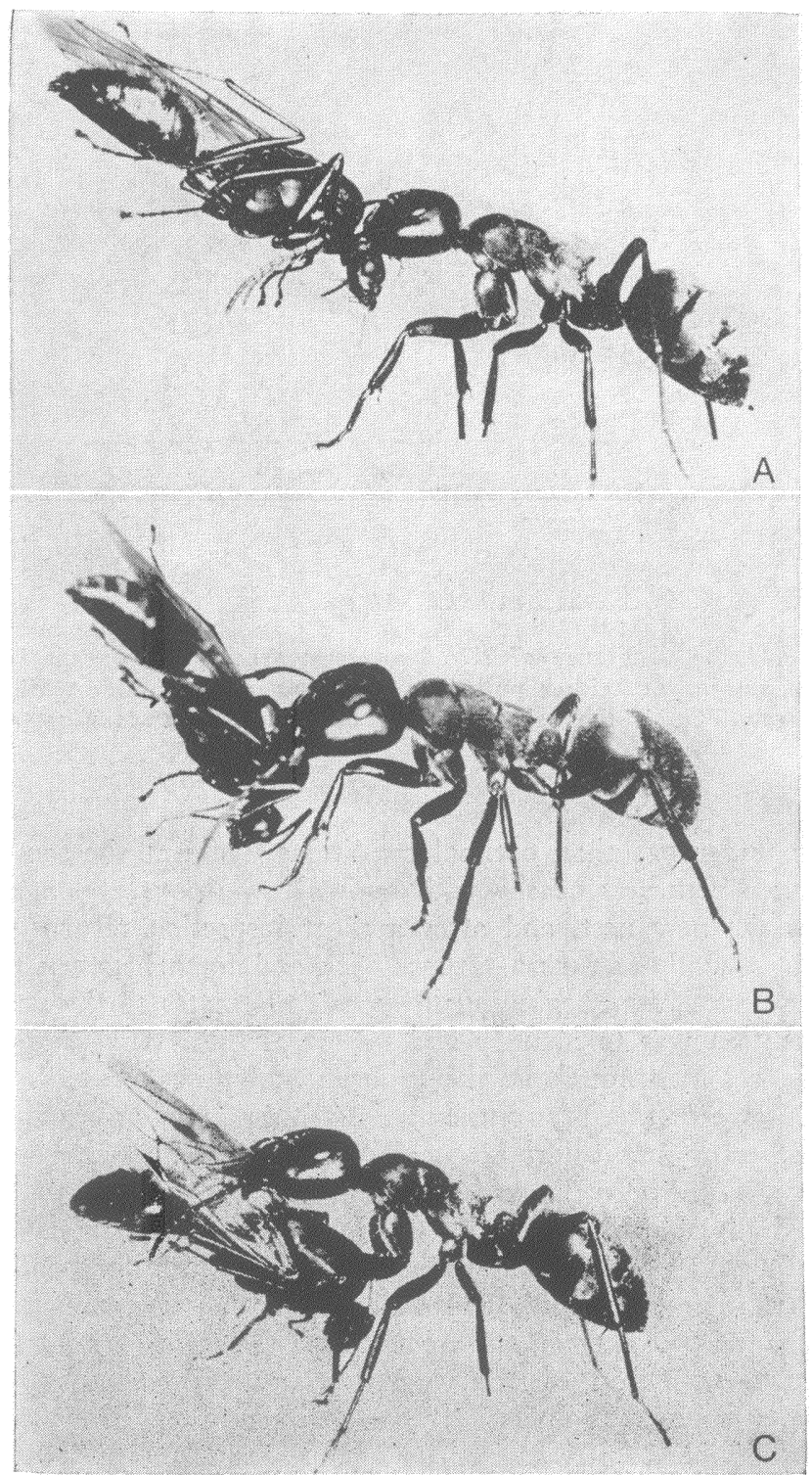

Fig. 6. Male transport in Camponotus sericeus: A) Commonly used technique. B) and C) Exceptionally used techniques. 


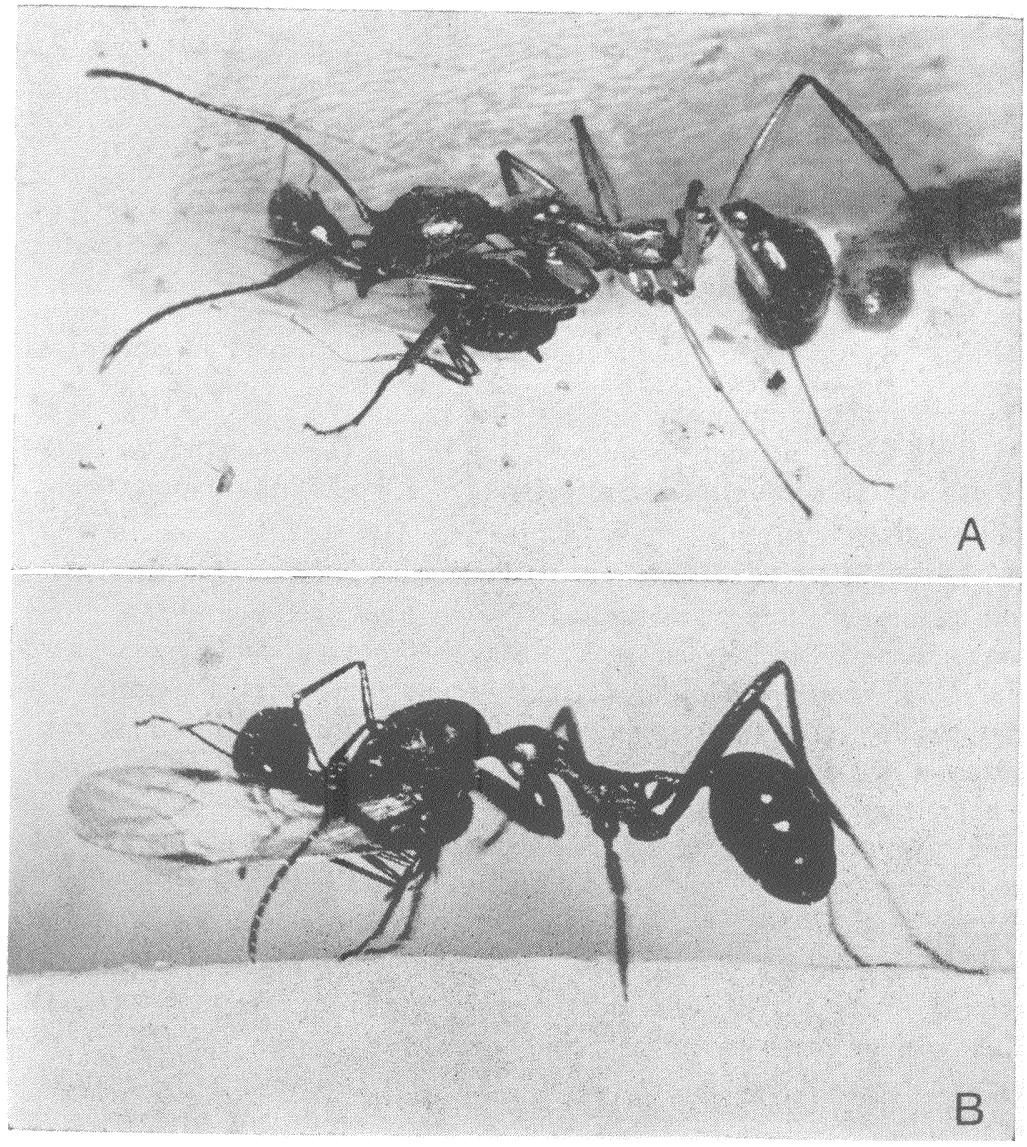

Fig. 7. Male transport in A) Aphaenogaster floridanus and B) Novomessor cockerelli. 
The intensity is defined as the total number of recruitment performances during the entire experimental period, independent how these performances were distributed over the nest movings. The continuity, on the other hand, is defined as the percentage of nest movings during which an individual worker acted at least once as a recruiting ant. 4) In order to rank degrees of specialization of different workers we combined all these parameters in an index which gives us a measure of the relative recruitment activity (RRA) of individual ants: $R R A=\frac{R_{a}}{R_{p}} \times C$. $R_{a}$ is defined as the total number of active recruitment acts performed by the individual ant; $R_{p}$ is the total number of recruitment episodes during which the ant acted as transportee or tandem follower, respectively, and $\mathrm{C}$ is the continuity, as defined above.

The quantitative records gathered for each individual worker during 20 nest movings, are summarized in Fig. 8 and 9. From these sociograms it can be seen that, although both species ( $F$. sanguinea and $C$. sericeus) use different recruitment techniques, the social organization of their nest movings is basically similar. The rest emigrations are organized by a pronounced system of division of labor. There is a relatively small group of workers (in our colonies II \% in $F$. sanguinea and $6 \%$ in $C$. sericeus) which were active in $80 \%$ of all nest moving experiments, and some individuals of this group recruited up to $3 \mathrm{I}$ nestmates during a single nest emigration.

This specialized group shows a significantly higher recruitment activity in comparison with all the other workers $\left(\mathrm{X}^{2}\right.$-test, $\left.\mathrm{p}=0.0 \mathrm{I}\right)$. The sociograms also reveal that even the mover specialists are sometimes transported themselves. This is especially the case at the beginning of a nest moving, when a single scout ant first recruits workers of the specialists' group. Those recruits subsequently become recruiters themselves. For $F$. sanguinea we recorded at least 7 cases where an ant has been carried to a target area and subsequently returned to the old nest to become a recruiter itself. The same procedure was demonstrated 20 times in $F$. polyctena. From those data we conclude that the carrying act can function as a complete recruitment procedure, by which the recruited ant is not only brought to the target area but also is stimulated to become an active recruiter itself. The same, of course, is true for the tandem running technique as previously documented (Hölldobler, Maschwitz, Möglich 1974).

The degree of specialization of division of labor in different colonies can be demonstrated by ranking the workers according to their 
RRA-indices and by plotting the rank positions against the index values (Fig. IO). In the test colonies of both species the curve declines rather steeply indicating that the degree of specialization is high. We were able to prove the crucial role of this small group of specialists simply by removing them from the colony and observing the performance of the workers left behind. Although some regulative replacements by other workers appeared to be possible, the time needed for moving was considerably increased. When we also removed this second mover group, the colony was almost unable to achieve an organized nest emigration, even when their nest conditions became very unfavorable. Workers left the nest and dispersed, but no organized nest emigration took place. From this we conclude that a specialized group of nest movers exists and is important in leading a colony in a relatively short period of time from unfavorable to favorable nest sites.

According to the investigations by Otto (1958) and Kneitz (1964) we should expect that the moving specialists belong to the so called outside workers (Aussendiensttiere) with reduced ovaries. The dissection of all workers of the colonies showed that indeed all movers had reduced ovaries, whereas the ovaries of many of the ants being carried or led were relatively well developed. However, from our invstigations it became also clear that only a small portion of the "Aussendiensttiere" function as mover specialists. If they are removed experimentally, they can be replaced by other workers with reduced ovaries, whereas nestworkers (Innendiensttiere) with well developed ovaries cannot substitute for lost mover specialists.

\section{Summary}

Adult transport behavior is a common social activity in many ant species. It is employed most frequently as a recruitment technique during emigration from one nest site to another. As verified in this report, the behavior patterns vary among species and are correlated with phylogenetic groupings.

The social organization of emigration, in particular the division of labor among workers during the process, was analyzed in two species, one of which recruits nestmates by carrying (Formica sanguinea) and the other by tandem running (Camponotus sericeus). In both cases it was found that only a special group of workers organizes nest emigrations. All these moving specialists have completely reduced ovaries whereas many of the carried or led ants have well developed ovaries. 

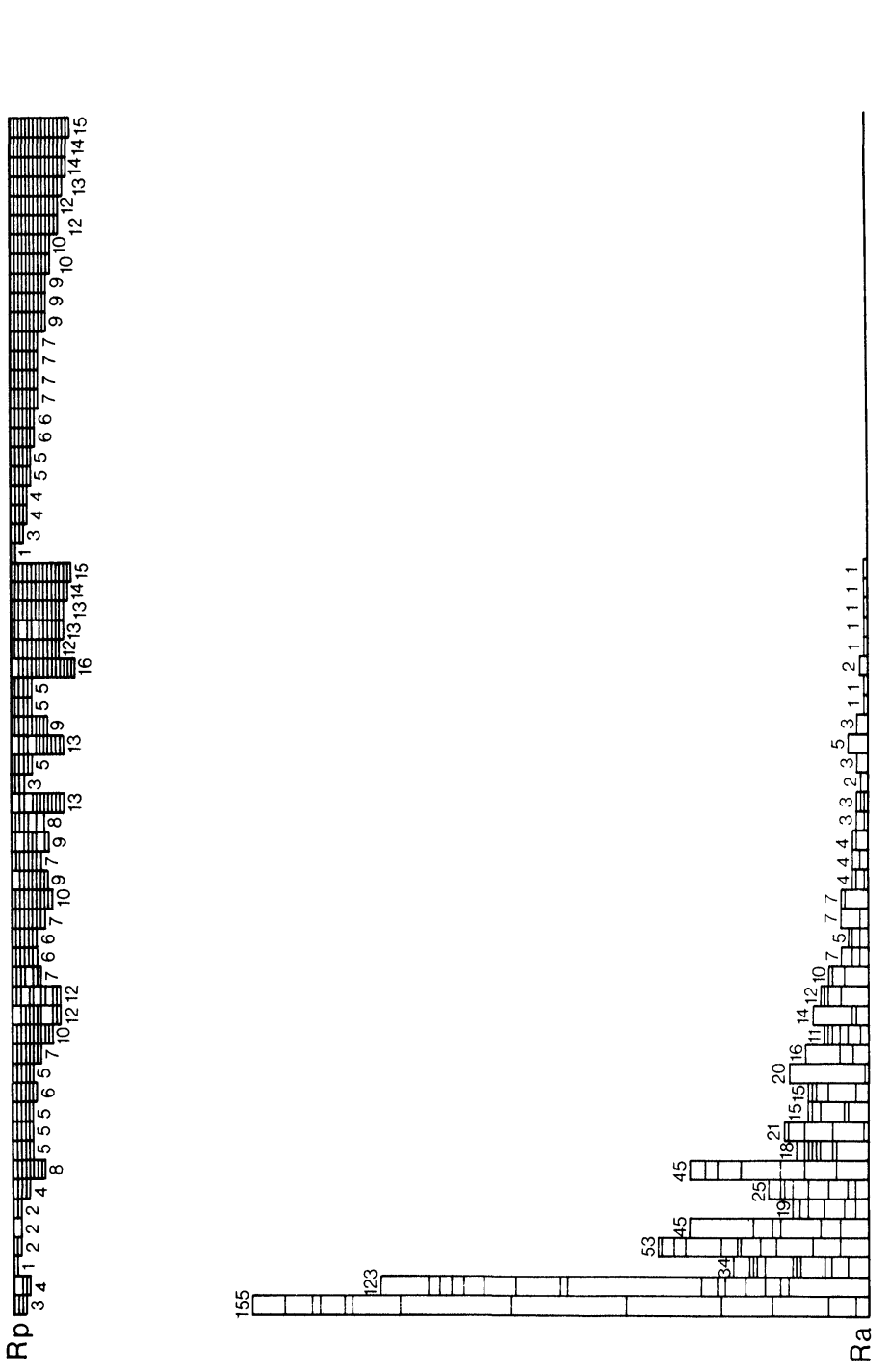

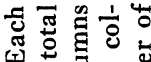
응 ڤ 능

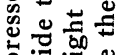
这. पर 幽 胥

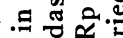
눙 릴. * 월 ๙ 콣

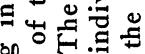
5 ن 월 혼 焉

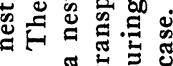
s 芯.马 ปั

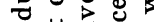

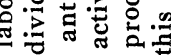

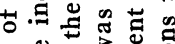

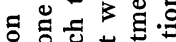

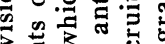
렁

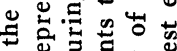

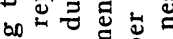
뽀를 ปี 월

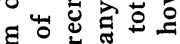

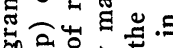
क्षे की ० 3

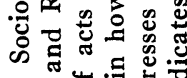
的

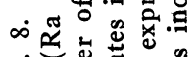

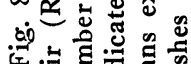

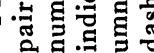



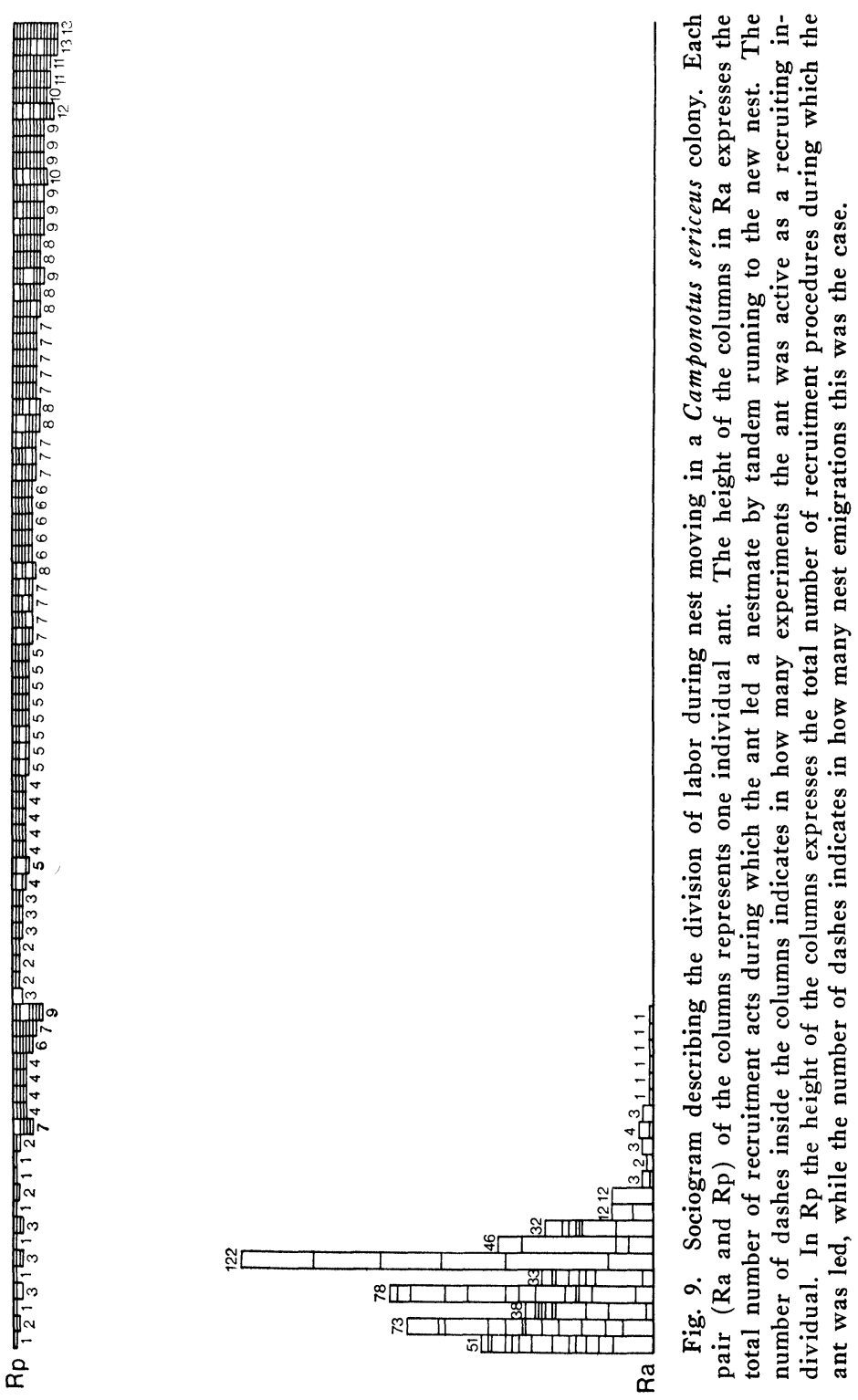


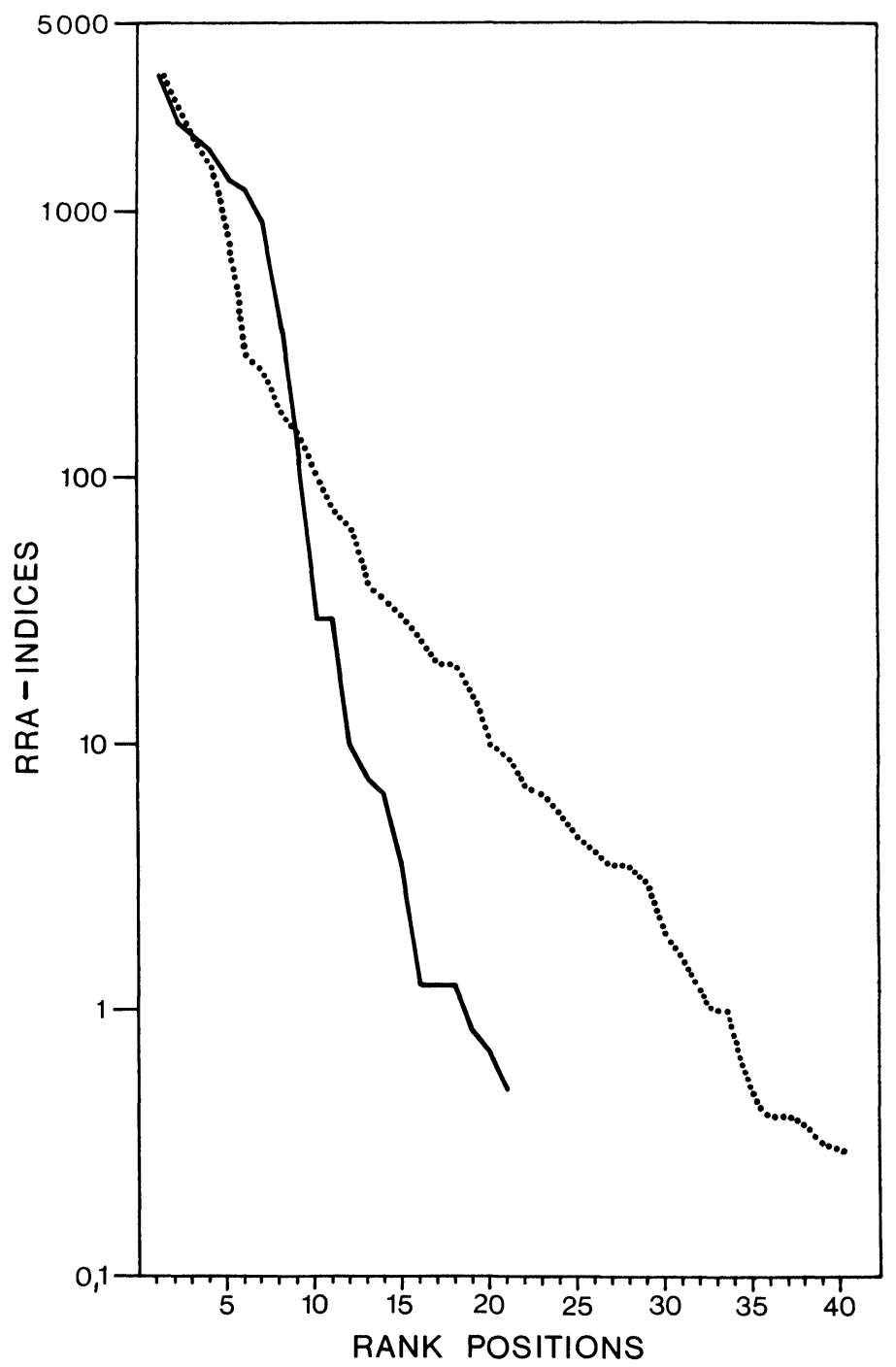

Fig. 10. Individual ants were ranked according to their relative indices. The rank positions (abscissa) are plotted against the index values (ordinate, logarithmic). The steepness of the curve directly represents the degree of specialization of the worker group.

Dotted line: Camponotus sericeus; solid line: Formica sanguinea. 


\section{Acknowledgements}

We would like to thank E. O. Wilson for critically reading the manuscript. The research has been supported by a grant from the National Science Foundation GB-38789XI.

\section{LiTERATURE}

ARNoLDI, $\mathrm{K}$.

1932. Biologische Beobachtungen an der neuen paläarktischen Sklavenhalterameise Rossomyrmex proformicarum K.Arn., nebst einigen Bemerkungen über die Beförderungsweise der Ameisen. $Z$. Morph. Ökol. Tiere 24: 319-326.

ESCHERISH, $K$.

1917. Die Ameise. Schilderung ihrer Lebenweise. Braunschweig, Friedr. Vieweg \& Son.

Haskins, C. P. and E. F. Haskins

1950. Notes on the biology and social behavior of the archaic ponerine ants of the genera Myrmecia and Promyrmecia. Ann. Entom. Soc. Amer. 43 : 461-491.

HöLLDOBLER, B.

1971. Recruitment behavior in Camponotus socius. Z. vergl. Physiol. 50: 551-568.

HölLDOBLER, B. ANd U. MASChWitz

1964. Die Hochzeitsschwarm der Rossameise Camponotus herculeanus. Z. vergl. Physiol. 50: 551-568.

Hölldobler, B., U. Maschwitz and M. Möglich

1974. Communication by tandem running in the ant Camponotus sericeus. J. Comp. Physiol. 90 : 105-127.

KNeITZ, G.

1964. Saisonales Trageverhalten bei Formica polyctena Foerst (Formicidae). Ins. Soc. $11(2): 105-130$.

Maschwitz, U., B. Hölldobler, and M. MöGlich

In press. Tandemlaufen als Rekrutierungsverhalten bei Bothroponera tesserinoda Forel (Formicidae: Ponerinae). Z. Tierpsychol.

MöGLICH, M.

1971. Nestumzugs- und Trageverhalten bei Ameisen. Staatsexamensarbeit an der Universität Frankfurt.

Oтто, D.

1958. Über die Arbeitsteilung im Staate von Formica rufa rufopratensis minor Gössw. und ihre verhaltensphysiologischen Grundlagen. Wiss. Abh. Deutsch. Akad. Landwirschaftswissenschaft. Berlin, Nr. 30.

RetTenmeyer, C.

1963. Behavioral Studies of Army Ants. Sci. Bull. Univ. Kansas 44: 281-465. 
WeHNer, R. ANd P. LUTZ

1969. Orientierungsmechanismen beim Nestbauverhalten der Wüstenameise Cataglyphis bicolor Fab. Natur und Museum 99: 177189.

WiLson, E. O.

1971. The Insect Societies. Belknap Press of Harvard University Press, Cambridge, Mass.

ZAHN, M.

1957. Temperatursinn, Wärmehaushalt und Bauweise der Roten Waldameise Formica rufa L. Zool Beitr. 3: 127-194. 

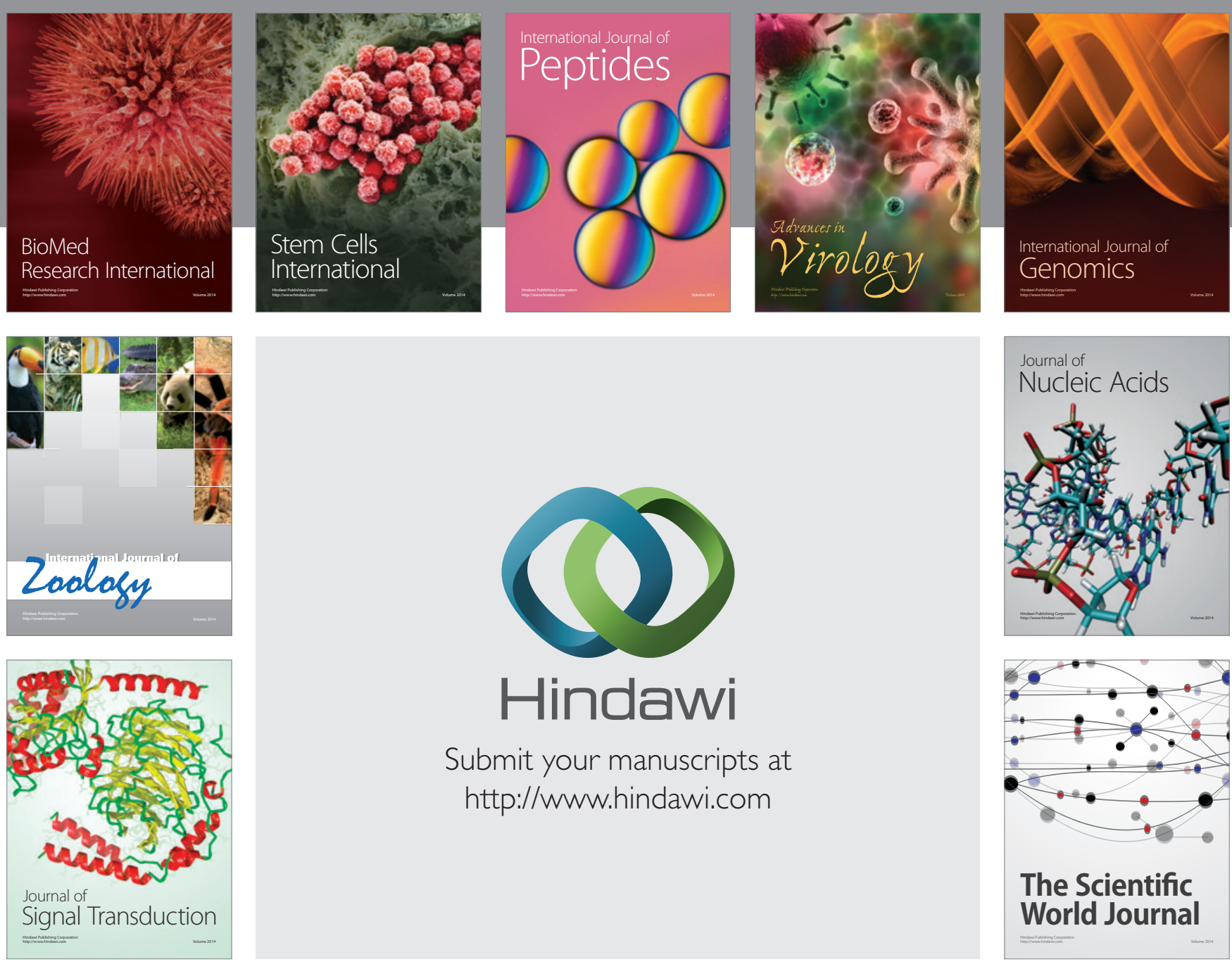

Submit your manuscripts at

http://www.hindawi.com
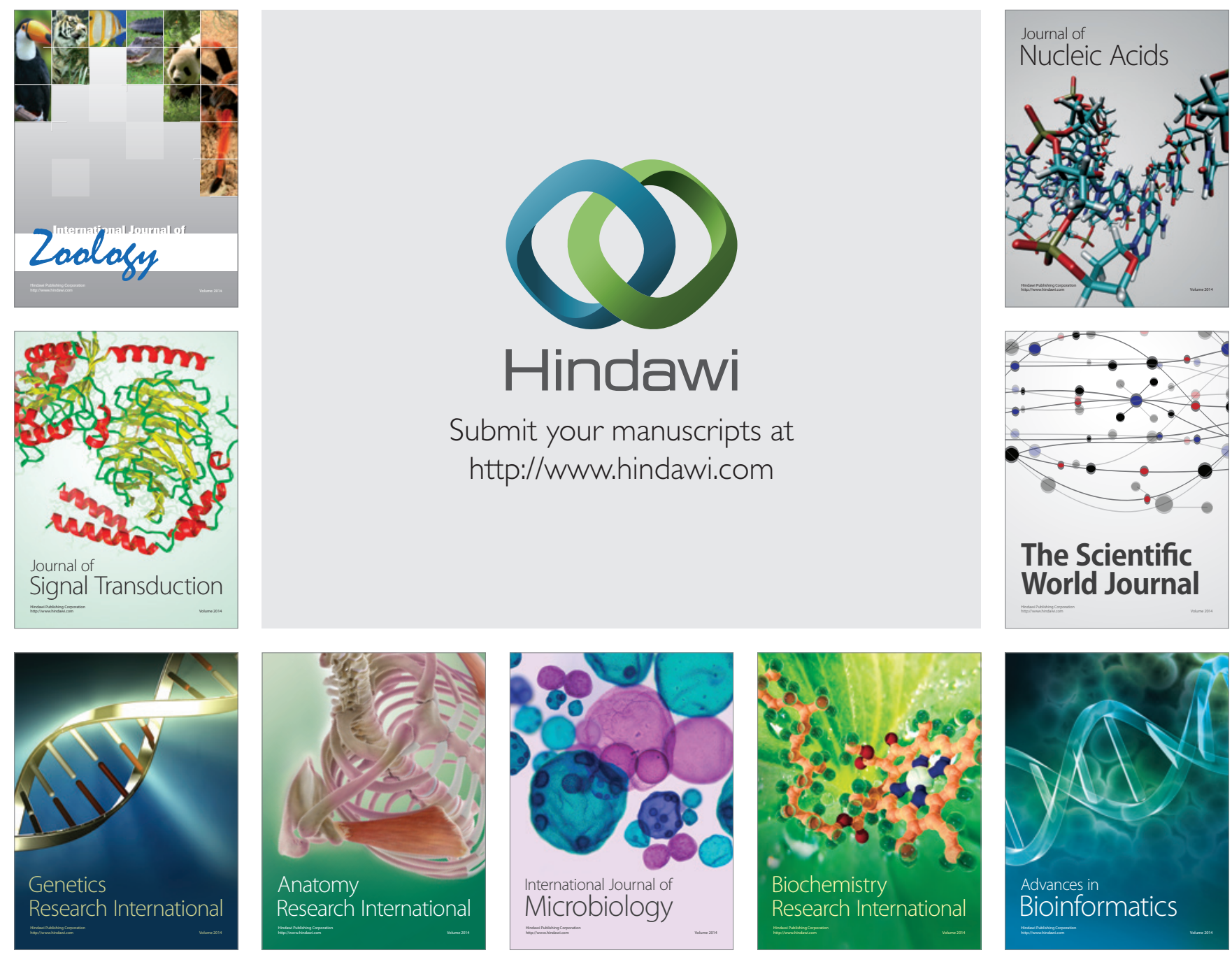

The Scientific World Journal
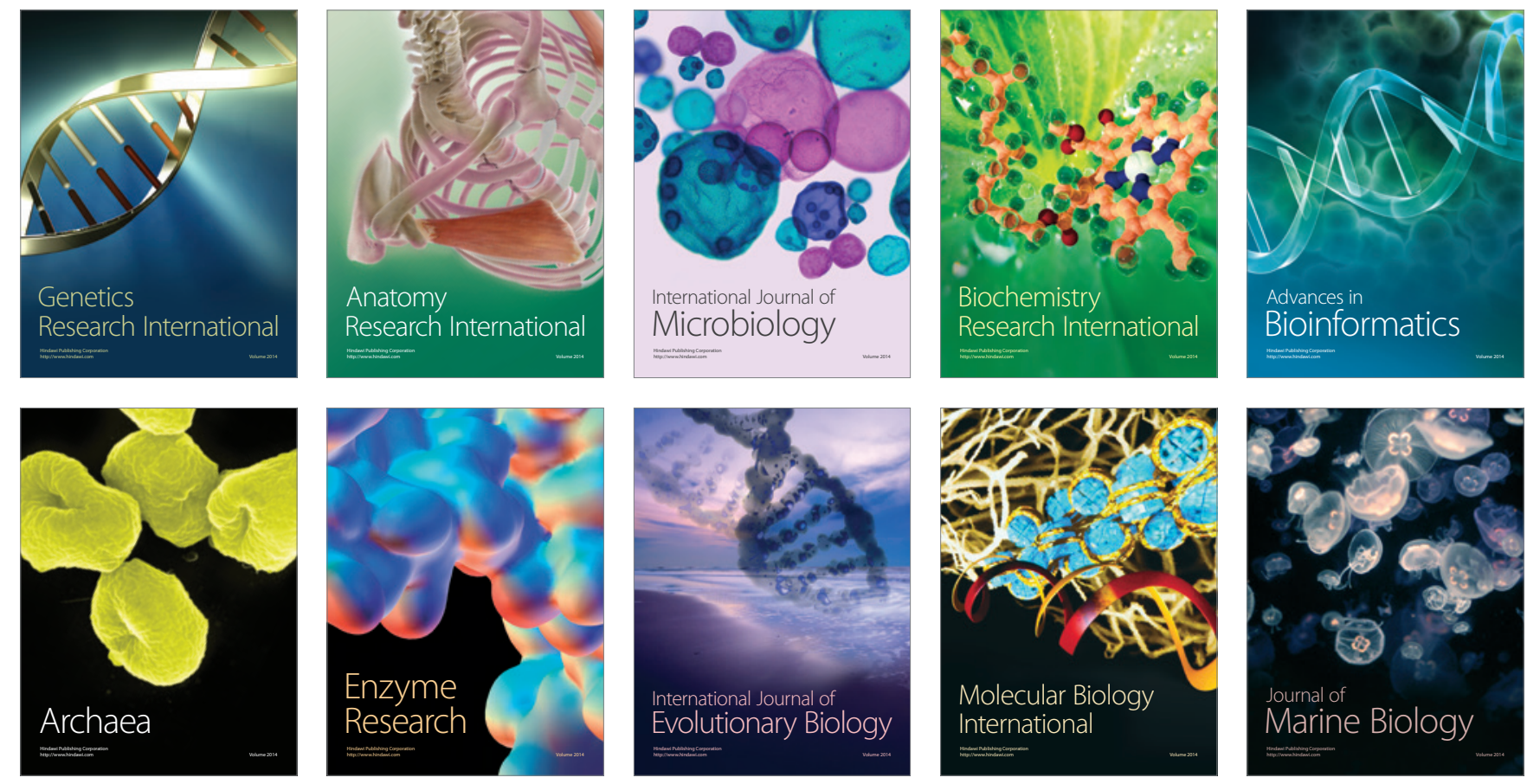